\title{
Preventing tipburn in chinese cabbage by high relative humidity during the night
}

\author{
N. van Berkel \\ Glasshouse Crops Research Station, P.O. Box 8, NL 2670 AA Naaldwijk, Nether- \\ lands
}

Received 4 March 1988; accepted 11 April 1988

Key words: tipburn, chinese cabbage, Brassica pekinensis ((Louv.) Rupr.), Ca spraying, relative humidity, electrical conductivity

\begin{abstract}
An experiment was conducted to determine whether by improved calcium supply of the young leaves, tipburn could be prevented in commercially grown chinese cabbage (Brassica pekinensis ((Louv.) Rupr.). Polyethylene sheeting was used to maintain a high relative humidity (RH) at night so that a root pressure flow could develop. Plants were watered with nutrient solutions having electrical conductivities (EC) of $1.5,3.0$ or $4.5 \mathrm{dS} \mathrm{m}^{-1}\left(25^{\circ} \mathrm{C}\right)$ and half the number of plants was sprayed with a $0.7 \%(\mathrm{w} / \mathrm{v}) \mathrm{Ca}\left(\mathrm{NO}_{3}\right)_{2}$ solution.

About complete prevention of tipburn incidence was obtained at high RH during the night in combination with a low EC of the nutrient solution. Calcium spraying under these conditions did not give a further decrease of tipburn. The results are discussed against the background of the technical possibilities of realizing high night RH in greenhouses.
\end{abstract}

\section{Introduction}

In the Netherlands, the cultivation of chinese cabbage (Brassica pekinensis ((Louv.) Rupr.) in greenhouses takes place from February-May and covers an area of about 30 ha. One of the factors limiting growers' interest is the incidence of tipburn. As yet there is no effective method to prevent tipburn.

Tipburn is a physiological disorder caused by calcium deficiency of the growing cells of young leaves (Shear, 1975). This results in a loss of membrane integrity and weakness of cell wall structures (Bangerth, 1979; Collier, 1982), which gives rise to a breakdown of the cells near the edges (tips) of the leaves. The onset of tipburn is rather complicated by the many aspects of the disorder. Therefore a short survey of the most relevant aspects is given.

The occurrence of tipburn largely depends on the ease with which water and nu- 
trients can be taken up from the soil. In general, a dry soil or a high nutrient concentration are conducive to the onset of tipburn (Sonneveld \& van den Ende, 1975; Bradfield \& Guttridge, 1979). Conditions favouring rapid growth also advance the onset of tipburn (Thibodeau \& Minotti, 1969; Bangerth, 1979). An increased growth rate implies that more developing cells are present and more calcium is needed per unit of time. So, tipburn developed quickly in young plants when they were exposed to high light intensities and to extended photoperiods (Tibbitts \& Rao, 1968), or to increased air temperatures (Cox et al., 1976).

Calcium shows a peculiar behaviour as far as its distribution within the plant is concerned. Calcium is passively transported by the water in the xylem and is stored at sites to which the waterstream is directed (Wiersum, 1966). No redistribution of calcium via the phloem does occur (Hanger, 1979).

With plants like lettuce, endive, cabbage and blanching celery, the outer leaves are well exposed and can transpire freely, whereas the inner leaves are poorly or not exposed and transpire much less or not at all (Collier, 1982).

With white cabbage, Wiebe et al. (1977) showed that calcium accumulated mainly in the outer leaves during daytime in dependence of the transpiration intensity, whereas in the inner head leaves calcium accumulated mainly during night time, when the head mass increased due to increasing plant water potential and due to growth.

Still more water with calcium can be transported to the inner leaves when a further increase of water pressure potential (root pressure) takes place. Palzkill \& Tibbitts (1977) and Palzkill et al. (1976) found heading cabbage guttating freely and staying completely free from tipburn when a humid atmosphere was created by covering the plants with plastic during the night. The same was experienced with chinese cabbage (van Berkel, 1981). Because of the plastic cover the relative humidity (RH) was increased to about $100 \%$. Consequently, the transpiration stopped and a positive root pressure could develop. Only a high RH during the night could prevent the occurrence of tipburn. A high day RH or a continuous high RH did not prevent the occurrence of tipburn in cabbage (Wiebe, 1975; Palzkill et al., 1980), in strawberry (Bradfield \& Guttridge, 1979) and in celery (Bible \& Stiehl, 1986).

Root pressure flow can only occur when soil conditions are favourable for water and nutrient uptake (Kramer, 1969).

Efforts were made to control tipburn in lettuce by spraying the young leaves, which are prone to tipburn, with a low-concentrated solution of calcium nitrate. This procedure appeared effective as long as the immature leaves could be wetted directly. When the leaves became enclosed by head formation, spraying had no longer effect (Kruger, 1966; Thibodeau \& Minotti, 1969).

Applying a mist, i.e. a high air humidity around the leaves during the night, reduced the number of tipburn plants to some extent in lettuce (Cox \& Dearman, 1981). Guttormsen (1985) also reduced the number of tipburn plants by wetting chinese cabbage plants several times a night. However, none of these efforts gave a complete prevention of tipburn.

Tipburn occurrence is not accepted at all in protected cultivation, also because suspected heads must be opened for inspection; this makes them less marketable. 
As shown above, a successful method to prevent tipburn occurrence completely is suppressing plant transpiration during night time to almost zero. Therefore, the use of a plastic cover was chosen as the main objective of the present study, in order to examine whether this is a suitable method to prevent tipburn in commercial greenhouse culture of chinese cabbage. The least laborious way was thought to be insulating a greenhouse compartment with polyethylene during the night.

\section{Materials and methods}

To obtain a relative humidity of about $100 \%$ (high $\mathrm{RH}$ ) in one half of a greenhouse compartment a wooden frame $(5 \times 4 \times 2 \mathrm{~m})$ was constructed. The side walls of the frame were clad with polyethylene. During the night the top of the frame was almost hermetically closed by a movable cover of polyethylene. To prevent the onset of condensation droplets, the polyethylene was coated with a substance which lowers the surface tension of water. The opening and closing of the cover was controlled by a time switch. In the other half of the greenhouse compartment no special measures were taken to control the relative humidity (normal $\mathrm{RH}$ ).

Ca sprayings were applied to half the plants of both $\mathrm{RH}$ treatments using an atomizer. Three times a week at 9.00 a.m., plants were sprayed with a $0.7 \%(\mathrm{w} / \mathrm{v})$ $\mathrm{Ca}\left(\mathrm{NO}_{3}\right)_{2}$ solution, whereas control plants were sprayed with demineralized water.

Plants were watered with nutrient solutions having electrical conductivities (EC) of $1.5,3.0$ or $4.5 \mathrm{dS} \mathrm{m}^{-1}\left(25^{\circ} \mathrm{C}\right)$. The nutrient solution with the lowest EC contained the following ions $\left(\mathrm{mmol} \mathrm{l}^{-1}\right)$ : $\mathrm{NO}_{3} 12, \mathrm{H}_{2} \mathrm{PO}_{4} 1.3, \mathrm{SO}_{4} 0.6, \mathrm{~K} 6.3, \mathrm{Ca} 2.8, \mathrm{Mg} \mathrm{0.9}$, and (in $\mu \mathrm{mol} \mathrm{I}^{-1}$ ) Fe 44, Mn 3, $\mathrm{Zn} \mathrm{4,} \mathrm{B} \mathrm{25,} \mathrm{Cu} \mathrm{0.6,} \mathrm{Mo} \mathrm{0.6.} \mathrm{In} \mathrm{the} \mathrm{solutions} \mathrm{with} \mathrm{EC}$ 3.0 and 4.5 the concentrations of the various ions were two times and three times as high, respectively. The $\mathrm{pH}$ of the solutions was about 5.8 . Within each spraying treatment the EC treatments were replicated in blocks three times. Each plot consisted of five plants.

One experiment was carried out with fourfold replication in time and space. Three of the four replicates were conducted in spring 1984, autumn 1984 and spring 1985 as described above. The fourth was conducted also in spring 1985, using an identical set-up. The treatments started at the beginning of head formation of the cabbage and lasted until harvest, i.e. from 20 March to 19 April 1984, from 15 October to 26 November 1984, from 13 March to 16 April 1985 and from 13 March to 18 April 1985.

The plants were grown $45 \times 33 \mathrm{~cm}$ apart in 151 buckets with a perforated bottom. To prevent plants from rooting into the greenhouse soil, the buckets were placed on wooden laths somewhat above soil level. The buckets were filled with a coarse peat thoroughly mixed with $5 \mathrm{~kg}$ Dolokal (ground magnesium limestone), $500 \mathrm{~g} \mathrm{PG}$ mix (14+16+18 + trace elements) and $150 \mathrm{~g}$ FTE 36 (fritted trace elements) per $\mathrm{m}^{3}$. The $\mathrm{pH}$ of the mixture was 5.8 .

Chinese cabbage cv. Hong Kong or cv. WR 60 was sown, transplanted in peat blocks and planted in the buckets about 6 weeks after sowing.

Watering was carried out using a trickle irrigation system. Several times a day during one minute, excess of nutrient solution was supplied in order to prevent salt 


\section{N. VAN BERKEL}

accumulation in the buckets. Several times the drain water was sampled to estimate EC.

The setpoints for greenhouse air temperature in spring were $21{ }^{\circ} \mathrm{C}$ by day and $16^{\circ} \mathrm{C}$ by night whereas the ventilation temperature setpoints were $5{ }^{\circ} \mathrm{C}$ higher. The setpoint temperatures in autumn were $19^{\circ} \mathrm{C}$ by day and $14^{\circ} \mathrm{C}$ by night. To stimulate transpiration the ventilation setpoints were only two centigrades higher. The high temperature regimes were chosen to accelerate plant growth which stimulates tipburn occurrence.

At harvest, the plants were weighed after their yellow, partly wilted or dead leaves (so-called declined leaves) were taken off and counted. Then the remaining leaves were taken off the stem and judged for tipburn symptoms. Plants having one or more leaves with tipburn were graded as tipburn plants. Also the number of leaves having tipburn symptoms was determined. The young leaves with a length of less than $12 \mathrm{~cm}$ were dried and analysed for $\mathrm{Ca}$ by atomic absorption spectrophotometry. The statistical analysis was carried out by the Analysis of Variance method.

\section{Results}

The setpoint temperatures were well-realized, but at bright weather conditions the air temperatures exceeded $28^{\circ} \mathrm{C}$ several times. The high night $\mathrm{RH}$ varied between $95-100 \%$, whereas the normal RH varied between 70 and $95 \%$. During daytime the RH fluctuated between 45 and $80 \%$.

The nutrient concentration in the drain water from the buckets was about the same as in the solution supplied.

Shortly after planting, the plants grown at high night $\mathrm{RH}$ showed guttation at sunrise, the most with plants at EC 1.5, the least at EC 4.5. After some weeks the plants at 1.5 and $3.0 \mathrm{dS} \mathrm{m}^{-1}$ still showed guttation. The strongest guttation was accompanied a few times by water soaking (glassiness) along the edges of the older leaves.

Moreover, the plants grown at the high night RH looked paler green and had significantly more declined leaves (Table 1 ). There were no significant differences be-

Table 1. Effects of night relative humidity $(\mathrm{RH})$ and $\mathrm{EC}\left(\mathrm{dS} \mathrm{m}{ }^{-1} ; 25^{\circ} \mathrm{C}\right)$ on the number of declined leaves and head weights $(\mathrm{g})$ of chinese cabbage.

\begin{tabular}{|c|c|c|c|c|c|c|}
\hline & \multicolumn{3}{|c|}{ Normal RH } & \multicolumn{3}{|c|}{ High RH } \\
\hline & $\mathrm{EC}$ & $\mathrm{EC}$ & $\mathrm{EC}$ & $\mathrm{EC}$ & $\mathrm{EC}$ & $\mathrm{EC}$ \\
\hline & 1.5 & 3.0 & 4.5 & 1.5 & 3.0 & 4.5 \\
\hline Number of declined leaves ${ }^{1}$ & 6.8 & 6.9 & 6.9 & 8.0 & 8.5 & 8.2 \\
\hline Head weight ${ }^{1}$ & 1286 & 1230 & 1169 & 1313 & 1305 & 1241 \\
\hline
\end{tabular}

${ }^{1}$ Declined leaves were taken from 3 replicates (27 plants), head weights from 36 plants. LSD (number of declined leaves $)(P<0.05) 0.45,(P<0.01) 0.60$. LSD (head weight) $(P<0.05) 51.9,(P<0.01) 69.5$. 
Table 2. Effects of night relative humidity (RH) and Ca spraying on the number of tipburn heads and leaves (between brackets) of chinese cabbage grown at different EC levels $\left(\mathrm{dS} \mathrm{m}^{-1} ; 25^{\circ} \mathrm{C}\right.$ ) of the nutrient solution.

\begin{tabular}{|c|c|c|c|c|}
\hline \multirow{3}{*}{$\begin{array}{l}\text { EC level } \\
\left(\mathrm{dS} \mathrm{m}^{-1}\right)\end{array}$} & \multicolumn{2}{|l|}{ Normal RH } & \multicolumn{2}{|l|}{ High RH } \\
\hline & without & with & without & with \\
\hline & Ca spraying & Ca spraying & Ca spraying & Ca spraying \\
\hline 1.5 & $31(658)$ & $30(287)$ & $3(10)$ & $2(4)$ \\
\hline 3.0 & $36(1252)$ & $34(527)$ & $12(62)$ & $20(181)$ \\
\hline 4.5 & $36(1543)$ & $28(414)$ & $32(454)$ & $30(427)$ \\
\hline
\end{tabular}

LSD (number of tipburn heads) $(P<0.05) 9.7,(P<0.01) 12.9$. LSD (number of tipburn leaves) $(P<$ $0.05) 228,(P<0.01) 306$.

tween head weights at both RH levels, but the weights decreased significantly with increasing $\mathrm{EC}$ in the range 3.0 to 4.5 .

In Table 2 the average numbers of tipburn heads of 36 plants and the average numbers of their tipburn leaves (between brackets) are presented. Tipburn leaves were found somewhere along the stem, upwards to the leaves shorter than $12 \mathrm{~cm}$. At the high night $\mathrm{RH}$ (without Ca spraying) almost complete prevention of tipburn incidence was observed only at $1.5 \mathrm{dS} \mathrm{m}^{-1}$ (Table 2). At the higher EC levels the number of tipburn heads increased significantly. At the normal night RH only a few plants remained free from tipburn at $1.5 \mathrm{dS} \mathrm{m} \mathrm{m}^{-1}$ whereas all plants were injured at EC 3.0 and 4.5. At both night RHs (at high night RH only between EC 3.0 and 4.5) the number of tipburn leaves per head increased significantly with increasing EC indicating tipburn occurrence started earlier viz. on leaves grown lower along the stem.

Spraying with calcium did not significantly affect the number of tipburn heads. However, at the normal RH the number of tipburn leaves was significantly reduced, whereas at the high RH no effect was observed.

At the high RH (without Ca spraying) the Ca concentrations of the inner leaves (length $<12 \mathrm{~cm}$ ) were significantly higher than at the normal RH (Table 3). At both

Table 3. Effects of night relative humidity ( $\mathrm{RH}$ ) and Ca spraying on Ca concentration ( $\mathrm{mmol} \mathrm{kg}^{-1} \mathrm{dry}$ weight) in the inner leaves $\left(<12 \mathrm{~cm}\right.$ length) of chinese cabbage grown at different EC levels $\left(\mathrm{dS} \mathrm{m}^{-1}\right.$; $25^{\circ} \mathrm{C}$ ) of the nutrient solution.

\begin{tabular}{|c|c|c|c|c|}
\hline \multirow{3}{*}{$\begin{array}{l}\text { EC level } \\
\left(\mathrm{dS} \mathrm{m}^{-1}\right)\end{array}$} & \multicolumn{2}{|l|}{ Normal RH } & \multicolumn{2}{|l|}{ High RH } \\
\hline & without & with & without & with \\
\hline & Ca spraying & Ca spraying & Ca spraying & Ca spraying \\
\hline 1.5 & 123 & 128 & 202 & 206 \\
\hline 3.0 & 94 & 126 & 169 & 163 \\
\hline 4.5 & 103 & 126 & 140 & 157 \\
\hline
\end{tabular}

$\operatorname{LSD}(P<0.05)=21.9,(P<0.01)=29.3$. 
RH levels, increasing EC, except from 3.0 to 4.5 at normal RH, gave significantly lower $\mathrm{Ca}$ concentrations of the inner leaves, despite the much higher $\mathrm{Ca}$ concentrations of the applied nutrient solutions at EC 3.0 and 4.5.

At the high $\mathrm{RH}$, calcium spraying did not affect the Ca concentrations of the inner leaves.

At the normal RH, calcium spraying led to higher Ca concentrations at EC 3.0 and 4.5 as compared with no Ca spraying, whereas no differences between Ca concentrations of the three EC levels were found.

\section{Discussion}

The results shown in Tables 2 and 3 demonstrate that a high relative humidity at night can prevent tipburn in chinese cabbage also when this crop is cultivated in a commercial way. This is in agreement with earlier results obtained in experiments in growth chambers/cabinets and tunnels with cabbage (Palzkill et al., 1976; Palzkill \& Tibbitts. 1977), strawberry (Bradfield \& Guttridge, 1979) and chinese cabbage (van Berkel, 1981).

Plants at EC $1.5 \mathrm{dS} \mathrm{m}^{-1}$ stayed virtually free from tipburn if grown at high night $\mathrm{RH}$. The occurrence of a single tipburn leaf in these plants may be due to imperfect closing of the movable plastic cover during one night or another.

On commercial holdings in the Netherlands, temperature regimes are normally kept much lower than applied in this experiment. At present, growers start with temperatures of $16^{\circ} \mathrm{C}$ by day and $13{ }^{\circ} \mathrm{C}$ by night. To prevent tipburn occurrence by slowing down growth rate temperatures are lowered in the course of the growing period to $13{ }^{\circ} \mathrm{C}$ by day and $8{ }^{\circ} \mathrm{C}$ by night, or even lower. However, a spell of high spring temperature might give rise to heavy tipburn occurrence. This might be enhanced when low night air temperatures would cause soil temperatures that reduce uptake of water and nutrients (Kramer, 1969).

The satisfactory results in preventing tipburn in this experiment were obtained with high air temperatures. These results imply a method for complete prevention of tipburn if plants are grown at both high night RH and lower air temperatures.

With respect to quality, a lower air temperature also seems recommendable. Though the quality of all tipburn-free heads seemed to be sufficient, the fact that more of the leaves declined, together with the paler green colour of the heads may have consequences for the keeping quality of heads grown at high night RH. Further, attention has to be paid to achieve a lower relative humidity during daytime by ventilating on a wider scale, because this decreased growth and reduced tipburn occurrence in white cabbage (Wiebe, 1975) and lettuce (Collier \& Tibbitts, 1984). However, not every decrease in growth rate does reduce tipburn occurrence. On the contrary, a decrease of growth rate caused by an increase of the nutrient solution concentration is accompanied by an increase of tipburn occurrence.

At high night RH. spraying with calcium had no effect on the number of tipburn heads and leaves, neither on the Ca concentration of young leaves.

The positive effect of high RH on suppressing tipburn could not be improved by Ca spraying. At normal RH the number of tipburn leaves was significantly reduced 
by spraying with calcium, whereas the number of tipburn heads was only slightly decreased. Once more in this experiment it was demonstrated that after $\mathrm{Ca}$ spraying the onset of tipburn leaves was delayed to leaves higher along the stems. These leaves could no longer be reached because of head formation. This outcome is in agreement with the results of other workers (Kruger, 1966; Thibodeau \& Minotti, 1969).

A calcium concentration of about $200 \mathrm{mmol} \mathrm{kg}^{-1}$ dry matter in young leaves $(<12$ $\mathrm{cm}$ ) seems necessary to prevent tipburn incidence.

Increasing $\mathrm{EC}$ at high night $\mathrm{RH}$ had a negative effect on the number of tipburn heads and leaves, and on the $\mathrm{Ca}$ concentration in young leaves, irrespective of $\mathrm{Ca}$ spraying. Increasing EC at normal night $\mathrm{RH}$ had the same effects if no Ca spraying was given. These effects are in agreement with findings of other workers (Sonneveld \& van den Ende, 1975; Bradfield \& Guttridge, 1979). However, at normal RH and with $\mathrm{Ca}$ spraying and increasing $\mathrm{EC}, \mathrm{Ca}$ concentrations of the young leaves were similar. whereas at EC 4.5 the number of tipburn leaves was relatively low. No explanation for these results was found.

At a high night $\mathrm{RH}$ the plants at EC $1.5 \mathrm{dS} \mathrm{m}^{-1}$ guttated freely. This, as well as the incidental occurrence of watersoaking along the leaf edges, is indicative of a high root pressure (van Berkel, 1981). The plants at EC 3.0 also guttated several times till harvest time but less intensively. Mere guttation does not keep plants free from tipburn. Probably a minimum quantity of water (duration $x$ intensity) with sufficient calcium has to pass the xylem for adequate supply of calcium as has been shown for cabbage (Palzkill et al., 1976) and strawberry (Bradfield \& Guttridge, 1979).

The technical possibilities to raise the relative humidity at night to about $100 \%$ offer perspectives for growing also other crops than chinese cabbage free from tipburn. Crops like endive, lettuce and blanching celery may profit by it as well. On the other hand, they also offer a good tool for a more comprehensive judgment of new leafy crops to be tested for cultivation in greenhouses. Many of these crops show tipburn symptoms rather early. Until now, they were consequently rejected or suggested to be adapted to greenhouse conditions by breeding.

\section{References}

Bangerth, F.. 1979. Calcium-related disorders of plants. Annual Review of Phytopathology 17: 97-122.

Berkel. N. van. 1981. Three physiological disorders. Acta Horticulturae 119: 77-90.

Bible. B. B. \& B. Stiehl. 1986. Effect of atmospheric modification on the incidence of blackheart and the cation content of celery. Scientia Horticulturae 28: 19-28.

Bradfield. E. G. \& C. G. Guttridge. 1979. The dependence of Ca transport and leaf tipburn in strawberry on RH and nutrient solution concentration. Annals of Botany 43: 365-372.

Collier, G. F.. 1982. Tipburn of lettuce. Horticultural Reviews 4: 49-65.

Collier. G. F. \& T. W. Tibbitts. 1984. Effects of RH and root temperature on Ca concentration and tipburn development in lettuce. Journal of the American Society for Horticultural Science 109: 128-131.

Cox, E. F. \& A. S. Dearman. 1981. The effect of trickle irrigation, misting and row position on the incidence of tipburn of field lettuce. Scientia Horticulturae 15: 101-106.

Cox. E. F.. J. M. T. McKee \& A. S. Dearman, 1976. The effect of growth rate on tipburn occurrence in lettuce. Journal of Horticultural Science 51: 297-309. 
Guttormsen. G., 1985. Effects of air humidity and temperature on chinese cabbage grown in greenhouses. Forskning og Forsøk in Landbruket 36: 81-89.

Hanger, B. C., 1979. The movement of calcium in plants. Communications in Soil Science and Plant Analysis 10: 171-193.

Kramer, P. J., 1969. Plant and soil water relationships: a modern synthesis. 347 pp. McGraw-Hill, New York.

Kruger, N. S., 1966. Tipburn of lettuce in relation to Ca nutrition. Queensland Journal of Agricultural and Animal Science 23: 379-385.

Palzkill, D. A. \& T. W. Tibbitts, 1977. Evidence that root pressure flow is required for Ca transport to head leaves of cabbage. Plant Physiology 60: 854-856

Palzkill, D. A., T. W. Tibbitts \& B. E. Struckmeyer, 1980. High relative humidity promotes tipburn on young cabbage plants. HortScience 15: 659-660.

Palzkill, D. A.. T. W. Tibbitts \& P. H. Williams, 1976. Enhancement of Ca transport to inner leaves of cabbage for prevention of tipburn. Journal of the American Society for Horticultural Science 101: 645648 .

Shear, C. B. . 1975. Calcium-related disorders of fruits and vegetables. HortScience 10: 361-365.

Sonneveld, C. \& J. van den Ende, 1975. The effect of some salts on head weight and tipburn of lettuce and on fruit production, and blossom-end rot of tomatoes. Netherlands Journal of Agricultural Science 23: 191-201.

Thibodeau, P. O. \& P. L. Minotti, 1969. The influence of Ca and the development of lettuce tipburn. Journal of the American Society for Horticultural Science 94: 372-376.

Tibbitts, T. W. \& R. R. Rao, 1968. Light intensity and duration in the development of lettuce tipburn. Proceedings of the American Society for Horticultural Science 93: 454-461.

Wiebe, H. J., 1975. Relation between the water status of the plant and the occurrence of internal tipburn in white cabbage (in German, with English summary). Gartenbauwissenschaft 40: 134-138.

Wiebe, H. J., H. P. Schätzler \& W. Kühn, 1977. On the movement and distribution of Ca in white cabbage in dependence of the water status. Plant and Soil 48: 409-416.

Wiersum, L. K., 1966. Ca content of fruits and storage tissues in relation to the mode of water supply. Acta Botanica Neerlandica 15: 406-418. 